\title{
Chemistry and Biological Activity of Condamineeae Tribe: A Chemotaxonomic Contribution of Rubiaceae Family
}

\author{
Vinicius F. Moreira*, Ivo J. C. Vieira, Raimundo Braz-Filho \\ Sector of Natural Products Chemistry, Universidade Estadual do Norte Fluminense Darcy Ribeiro, Campos dos \\ Goytacazes, Brazil \\ Email: ${ }^{*}$ fmoreira@gmail.com
}

Received 30 August 2015; accepted 20 October 2015; published 23 October 2015

Copyright (C) 2015 by authors and Scientific Research Publishing Inc.

This work is licensed under the Creative Commons Attribution International License (CC BY). http://creativecommons.org/licenses/by/4.0/

(c) (i) Open Access

\begin{abstract}
This study is a review of the Condamineeae tribe, through the acquisition of data from phytochemical studies and evaluation of genera activities that constitute the tribe, in order to contribute to chemotaxonomic classification of this tribe in the Rubiaceae family. This review also states the scarcity of phytochemical investigations of several genera and consequently a lot of species of family.
\end{abstract}

Keywords

Biological Activity, Condamineeae, Chemotaxomy, Phytochemistry, Rubiaceae

\section{Introduction}

The Rubiaceae family has approximately 660 genus and around 11,150 species [1]. Based on molecular phylogenetic studies [2] [3] this family is partitioned in three subfamilies: Cinchonoideae, Ixoroideae and Rubioideae.

It is widely distributed, mainly on tropical and subtropical regions but also on cold and temperate regions in Europe and north of Canada [4]. In America this family is represented by approximately 229 genus and 5200 species [5]. Nowadays it has around 118 genus and 1347 species in Brazil, corresponding to one of the main families of Brazilian flora [6].

This vast family is composed by classes of secondary metabolites with highly significant pharmacological potential. Into these classes the iridoids, anthraquinones, triterpenes and indole alkaloids, which are considered chemotaxonomic markers of the family [7], are highlighted. Many of chemical constituents as flavonoids, other

*Corresponding author.

How to cite this paper: Moreira, V.F., Vieira, I.J.C. and Braz-Filho, R. (2015) Chemistry and Biological Activity of Condamineeae Tribe: A Chemotaxonomic Contribution of Rubiaceae Family. American Journal of Plant Sciences, 6, $2612-2631$.

http://dx.doi.org/10.4236/ajps.2015.616264 
phenolic derivates and terpenoids (diterpens) are also found on this family.

In Ixoroideae subfamily the iridoids are presented as chemotaxonomic markers, while in Cinchonoideae there is a predominance of indolic alkaloids. In Rubioideae, the antraquinoms are the main class of secondary metabolites found [8]. Although the chemotaxonomic markers of Ixoroidae, it is also observed the occurrence of iridoids in the remaining subfamilies.

\section{Methods}

The data survey was done through academic researches and database sites and portals: www.ibict.br, www.scielo.org, www.sciencedirect.com, https://scifinder.cas.org, and www.periodicos.capes.gov.br. The terms used on the search strategy of scientific publications were restricted to species, genera, subfamilies, families and tribes. Aiming to provide greater scope to the bibliographic survey there were also selected some specific terms related to phytochemical and biological activities.

The academic investigations and scientific publications obtained for each genus are classified and presented in this study into four items: phytochemical studies, biological activities, ethno pharmacological activities and other studies, according to the available information.

\section{The Genera of Condamineeae Tribe-Ixoroideae Subfamily}

The Ixoroideae subfamily is represented by trees or scrubs and is characterized by levogyrous or valvular aestivation in most tribes. It presents pantropical e pan subtropical distribution and is composed by 15 tribes, including the Condamineeae, tribe that Simira genus belongs [9].

Phylogenetic molecular investigations revealed several relations on Rubiaceae systematic [10]. In a study conducted by [2] an initially divergent clade of the Ixoroideae subfamily was composed by genus previously classified into several distinct tribes, including Calycophylleae, Cinchoneae, Condamineeae, Hippotideae, and Rondeletieae. This clade was considered asan unique tribe and referred as Condamineeae, composed by the genus Alseis, Calycophyllum, Capirona, Chimarrhis, Condaminea, Emmenopterys, Pentagonia, Pinckneya, Pogonopus, Rustia, Simira and Warszewiczia [11].

Phylogenetic molecular studies associates several other genus to Condamineeae, such as Bathysa, Bothriospora, Dioicodendron, Dolichodelphys, Ferdinandusa, Hippotis, Macbrideina, Macrocnemum, Mastixiodendron, Parachimarrhis, Picardaea, Sommera and Wittmackanthus [3], and Mussaendopsis [12]. The Dialypetalanthus genus seemed to belong to Ixoroideae subfamily [13] and later classified as part of Condamineeae tribe [9].

The Condamineeae tribe is constituted by species very different morphologically wherein rare morphological characteristics of Rubiaceae are found into the tribe. The genus that compose the tribe are presented on Table 1 [11].

The result of bibliographic survey showed that only genres Alseis, Bathysa, Calycophyllum, Chimarrhis, Condaminea, Elaeagia, Emmenopterys, Pentagonia, Pogonopus, Rustia, Simira, Sommera and Warszewiczia had some type of phytochemical study. Presented studies evaluating biological activity, genres Alseis, Bathysa, Calycophyllum, Capirona, Chimarrhis, Elaeagia, Emmenopterys, Macrocnemum, Pentagonia, Pogonopus, Simira, Sommera and Warszewiczia. E ethnopharmacological activity reports to the generos A lseis, Bathysa, Bothriospora, Calycophyllum, Capirona, Condaminea, Hippotis, Macrocnemum, Pentagonia, Pogonopus, Rustia, Simira, Sommera and Warszewiczia.

The results of the literature survey data related to the genres of Condamineeae tribe is presented below, with the exception of Simira genre, which has already been presented in our previous research [14].

\subsection{Alseis}

\subsubsection{Phytochemical Studies}

It was found only one screening with 299 samples representing 133 species from 48 genera of plants of Panama Rubiaceae family. Samples of each extract were diluted in ammonia and chloroform for acid-base extraction to produce the alkaloids extracts. The extractions were applied on filter paper to comparison effects with emetine, with Dragendorff reagents. The samples were also chromatographed in silica gel plates for TLC with standards and pulverized with Dragendorff and $\mathrm{FeCl}_{3} / \mathrm{HClO}_{4}$ reagents to detect the presence of alkaloids. The A. blackiana species presented positive results for alkaloids on these chromatographic tests [15]. 
Table 1. Genera that constitutes the Condamineeae tribe.

\begin{tabular}{ccc}
\hline & Condamineeae & \\
\hline Alseis & Bathysa & Bothriospora \\
Calycophyllum & Capirona & Chimarrhis \\
Condaminea & Dialypetalanthus & Dioicodendron \\
Dolichodelphys & Dolicholobium & Elaeagia \\
Emmenopterys & Ferdinandusa & Hippotis \\
Holtonia & Macbrideina & Macrocnemum \\
Mastixiodendron & Mussaendopsis & Parachimarrhis \\
Pentagonia & Picardaea & Pinckneya \\
Pogonopus & Rustia & Schizocalyx \\
Semaphyllanthe & Simira & Sommera \\
Tammsia & Warszewiczia & Wittmackanthus. \\
\hline
\end{tabular}

\subsubsection{Biological Activity}

A. yucatanensis extracts were tested to it effect upon the induced contraction by norepinephrine (NE) $0.3 \mu \mathrm{M}$ or $55 \mathrm{ml} \mathrm{KCl}$ in cropped aorta of free endothelial rings. The extract of $A$. yucatanensis shell presented vasoactive activity (relaxed vase) being capable of relax induced contractions by NE and KCL with effective dose for 50\% (ED50) of 0.12 and $1.73 \mathrm{mg} / \mathrm{mL}$; respectively [16] [17].

\subsubsection{Ethnopharmacological Activity}

It was found only one ethnopharmacological investigation citing A. floribunda in a survey of plants named "bitter plants” used as substitutes of Chinchona spp. on Brazilian traditional medicine [18].

\subsection{Bathysa}

\subsubsection{Phytochemical Study}

It is noteworthy the phytochemical study that isolated the paeonol phenolic compound (1) of B. meridionalis roots (Figure 1) [19].

Positive results are found for indolic alkaloids and flavonoids on chromatographic tests with B. australis extracts analyzed by HPLC [20]. For B. cuspidata the presence of alkaloids was evaluated by thin layer chromatography [21] and phytochemical analyzes were done through chromatographic reagent tests to the presence of flavonoids, phenolic compounds, alkaloids, tannins, cumarins and triterpenes [22].

Studies with stem extracts of $B$. veraguensis species, as well as to B. panamensis [15], also presented positive results on TLC chromatographic tests (with Dragendorff reagents) to alkaloids [23].

\subsubsection{Biological Activity}

Special emphasis is given to studies evaluating the antifungal activity of secretory proteins of $B$. nicholsonii against Fusarium oxysporum, Colletotrichum musae e Colletotrichum lindemuthianum. The inhibition of fungal growth was tested with conidia (20,000 cells/mL in $1 \mathrm{~mL}$ of saline solution) incubated under $28^{\circ} \mathrm{C}$ in microplates of $200 \mu \mathrm{L}$, followed by addition of the exudates (secretory proteins) to a final concentration of $100 \mu \mathrm{g} / \mathrm{mL}$, revealing an inhibitory effect on the growth around 15\%, 20\% and 64\%, respectively, after $48 \mathrm{~h}$ [24].

Inhibitory activity evaluation of $B$. australis against Mycobacterium fortuitum and M. malmoense using the resazurin as a viable cell indicator, the crops were placed on microplates in contact with the extracts to be evaluated, in raw and partition forms. It was incubated under $37^{\circ} \mathrm{C}$ and after 48 hours, for M. malmoense, and four days, for $M$. fortuitum, it was added the resazurin. Firstly it was done the susceptibility screening to determine the activity of extracts and partitions of vegetable extracts in fixed concentrations $(100 \mu \mathrm{g} / \mathrm{mL})$. The B. australis extracts did not inhibited the growth of the microorganisms involved [25].

The ethanolic extract of B. australis was evaluated on the activity of the protein Pdr5p ATPase of plasmatic 
<smiles>COc1ccc(C(C)=O)c(O)c1</smiles>

(1)

\section{Figure 1. Chemical Structure of paeonol.}

membranes of yeasts, on concentration ranges of 0 to $400 \mu \mathrm{g} / \mathrm{mL}$ with $\mathrm{IC}_{50}$ of $35.3 \mu \mathrm{g} / \mathrm{mL}$. Based on this result the ethanolic extract was fractionated by liquid-liquid partition resulting in hexane, dichloromethane, ethyl acetate and butanol fractions. After the solubilization in $20 \%$ of dimethylsulfoxid, the fractions were tested in Pdr5p ATPase on fixed concentration of $200 \mu \mathrm{g} / \mathrm{mL}$ and it was observed that the ethyl acetate, dichloromethane and hexane fractions presented and inhibition on the Pdr5p ATPase activity very similar (around 80\%) compared with the ethanolic raw extract, while the butanol fraction produced a very small inhibition (around 20\%) [20].

The antifungal evaluation of $B$. meridionalis, against Alternaria anternata, that causes diseases on tangerines. The methanolic extracts of leaves, bark, flowers and stems were dissolved in $500 \mu \mathrm{L}$ of $1 \%(\mathrm{v} / \mathrm{v})$ of Tween 80 and mixed with $100 \mu \mathrm{L}$ of suspended conidae of $A$. anternata in $2.6-3.0 \times 10^{5}$ conidae/ml and the conidae suspension resultant was poured in pits (Pfizer, $0.55 \mathrm{mg} / \mathrm{ml}$ de PDA). After three days at $25^{\circ} \mathrm{C}$ and a 12 hours photoperiod, the extracts that hindered the fungal growth were considered active. The $B$. meridionalis extracts did not presented any significant result [26].

On a study of the effect of the bark extract of B. cuspidata in pulmonary injuries induced by paraquat (PQ) herbicide in rats, briefly, PQ was dissolved in $0.5 \mathrm{~mL}$ of $\mathrm{NaCl}$ saline solution at $0.9 \%(10 \mathrm{mg} / \mathrm{mL})$ and injected intraperitonially in a unique dose of $30 \mathrm{mg} / \mathrm{kg}$ of corporal weight. The ethanolic extract of B. cuspidata bark of the stem was resuspended in $700 \mu \mathrm{L}$ of DMSO vehicle and administrated for animals through wash. In the investigation the intoxicated rats' treatments, with 200 and $400 \mathrm{mg} / \mathrm{kg}$ of ethanolic extract, reduced the animal mortality to $30 \%$ and $20 \%$ respectively [27].

The hepatoprotective effect of the B. cuspidata bark extract on hepatic injury is induced by carbon tetrachloride. The hepatic injury was induced by intraperitoneal injection with administration of $\mathrm{CCl}_{4}(60 \% \mathrm{v} / \mathrm{v}, 1 \mathrm{ml} / \mathrm{kg})$ at each 48h during 12 days, the administration of the extract in $200 \mathrm{mg} / \mathrm{kg}$ and $400 \mathrm{mg} / \mathrm{kg}$ was started six days before the first application of $\mathrm{CCl}_{4}$ and progressed to be administrated to animals during the 12 days. A significant reduction on serum aspartate transaminase, alanine and gamma-glutamyl transferase and a significant increase on the activity of the antioxidant enzyme superoxide dismutase, low proportions of cellular necrosis and lipid droplets were observed, results that confirm the hepatoprotective activity pronounced of the bark extract of B. cuspidata and suggests this effect can be associated with the inhibition of oxidative damages [28].

Antioxidant effect of B. cuspidata extract on hepatic damage and glucose kinetic on rats' blood exposed to paraquat. On rats treated with $B$. cuspidata $(400 \mathrm{mg} / \mathrm{kg}$ ), the bark extract was capable of inhibit large glucose variations on blood and reduce the hepatic damage [22].

Yet for B. cuspidata studies are found evaluating the mutagenic potential of leaves and stems extracts tested by Ames test on TA98 and TA100 lines of Salmonella typhimurium on absence and presence of metabolic activation, revealing that the leaves ethanolic extract did not exert effect on plasmid DNA while the stem extract revealed mutagenic activity of metabolic activation on S. typhimurium. The extract effects directly on DNA were assessed by plasmodial cleavage, indicating the absence the genotoxic activity for both stem and leave extracts [21].

And finally, a study investigating the applicability potential of ethanolic extracts ointment from B. cuspidata's peel, for wounds treatment in Rats. The circular wounds of $12 \mathrm{~mm}$ diameter were done by surgical incision on the back of animals, which were divided in four groups, according to the received application. One group received a $0.9 \%$ saline solution, the second group received lanolin, and a third group received $2.5 \%$ of the lanolin emulsified extract. After 21 treatment days, the groups with the extract had given better results according to the skin regeneration and wound healing. This study suggests that the healing effects observed in ointment with the B. cuspidata's extract are related to polyphenols compounds, including flavonoids, found in these extracts and which had their presence identified by phytochemical tests [29].

To the B. veraguensis stem extracts were prepared and tested for inhibitory activity of acetylcholinesterase. A 
concentration of $100 \mu \mathrm{g}$ was applied on plates of TLC and eluted with a mix of $\mathrm{CHCl}_{3}-\mathrm{MeOH}_{-} \mathrm{H}_{2} \mathrm{O}$ (65:35:5) to polar extracts and AcOEt-n-hexane (1:1) to non-polar, respectively. The extracts revealed moderate inhibitory activity to acetylcholinesterase when compared to the $\mathrm{HBr}$ galatamine inhibitor tested at $0.01 \mu \mathrm{g}$ on TLC. On this same study the extracts of B. veraguensis were tested for inhibition activity to DPPH free moiety. The extracts revealed moderate activity of inhibiting the DPPH free moiety compared to quercetine, tested as reference compound $(0.1 \mu \mathrm{g})$ [23].

\subsubsection{Ethnopharmacological Activity}

For B. australis and B. cuspidata it was found an ethnophamacological study with a data survey of plants named "bitter plants" used as substitutes of Chinchona spp. on Brazilian traditional medicine [18].

\subsection{Bothriospora}

\section{Ethnopharmacological Activity}

It is noteworthy the ethnopharmacological study in biodynamic plants employed by the indians of amazonic region with medicines, poisons and narcotics. To B. corymbosa it is stated the use of fruits against intestine parasites [30].

\subsection{Calycophyllum}

\subsubsection{Phytochemical Study}

In a plant screening in Costa Rica the presence of alkaloids is found on leaves and stems of $C$. candidissimum through the chromatographic tests [31].

The phytochemical investigation of $C$. spruceanum presented the isolation of seco-iridoids 7-methoxydiderroside (2), 6'-O-acetyldiderroside (3) and 8-O-tigloyldiderroside (4), kingside (5), diderroside (6) and loganetin (7) (Figure 2), isolated from the wood bark along with the iridoids loganin (8) and secoxyloganin (9) (Figure 2) [32].

\subsubsection{Biological Activity}

To the species C. multiflorum, it was found an investigation of the antifungal activity evaluation of dichloromethane extracts, methanol and aqueous of the bark against Cryptococcus neoformans, Microsporum gypseum and Trichophyton mentagrophytes. The extracts were evaluated through the disc method-agar diffusion. The dichloromethane extract presented a pronounced activity, with $5 \mathrm{mg}$ per disc, diameters to the inhibition zone with<smiles>COC1OC=C(C(C)=O)C(CC(=O)O)C1C(C)OC(C)=O</smiles>

(2)<smiles>CC(=O)OC1=COC(CC(=O)O)C(C(C)=O)C1C(C)OC(C)=O</smiles>

(3)<smiles>CC=C(C)C(=O)OC(C)C1C(C(=O)O)=COC(OC)C1C(C)=O</smiles>

(4)<smiles>COC1C=CC(C(C)=O)[C@H](O)CC(=O)OC1C</smiles>

(5)<smiles>COC(=O)C1=CO[C@H](OC)[C@H]([C@@H](C)OC(C)=O)[C@@H]1CC(=O)O</smiles>

(6)<smiles>COC(=O)C1C[C@H](O)[C@H](C)[C@H]1C(O)O</smiles>

(7)<smiles>COC(=O)C1=COC(O)C2(C)C1CC(O)C(C)C2O</smiles><smiles>C=CC1C(C(=O)O)C(C(=O)O)=CO[C@@H]1OC</smiles>

(9)

(8) 
the values: $21 \mathrm{~mm}, 18 \mathrm{~mm}$ and $18 \mathrm{~mm}$, and to the dichloromethane extract with $10 \mathrm{mg}$ per disc, diameters to the inhibition zone with the values: $24 \mathrm{~mm}, 20 \mathrm{~mm}$ and $20 \mathrm{~mm}$ for C. neoformans, M. gypseum and T. mentagrophytes respectively. Besides, the aqueous extracts containing $5 \mathrm{mg}$ and $10 \mathrm{mg}$ per disc present inhibition diameters with the values 23 and 25 respectively to T. mentagrophytes [33].

Special emphasis is given to studies evaluating the activities of $C$. spruceanum against leishmania with MTT (3-(4,5-dimethiliazol-2ul)-2,5-difenil bromide of tetrazoline) presenting absence of activity [34].

The antimalarial evaluation of the bark of $C$. spruceanum in vivo determined by the suppression test of four days, and in vitro, the infected erythrocytes with malaria were sown on well of microtiter plates, exposed to different concentrations in both tests [35].

Yet, to C. spruceanum, the antibacterial evaluation against Mycobacterium tuberculosis the radiometric in vitro trials using semiautomatic detector for growth monitoring was applied. The raw extracts of dichloromethane of vegetal material were dissolved to the concentration of $1 \mathrm{mg} / \mathrm{ml}$ of $100 \%$ dimethilsulfoxid (DMSO) and injected on bottles to obtain a final concentration of $50 \mu \mathrm{g}$ of plant extract per $\mathrm{ml}$ of broth culture. The extracts presented less than $50 \%$ of inhibition, results considered non-significant [36].

The evaluation of antifungal activity against Candida albicans ATCC 90028, Sporothrix schenckii IHEM 15,503 and Trichophyton mantagrophytes IHEM 0584, in vitro, compared with amphotericin B. did not presented significant results [37].

The evaluation of the compounds 7-metoxididerrosideo, 6'-O-acethyldiderrosideo, secoxyloganin (9) and diderrode (6) exhibited poor activity in vitro against Trypanosoma cruzi with values of $\mathrm{IC}_{50}$ equal to 59, 0, 90, 2, 74,2 and $84.9 \mathrm{mg} / \mathrm{ml}$, respectively [32].

\subsubsection{Ethnopharmacological Activity}

The species C. acreanumi, C. obovatum and C. spruceanum are cited on an ethnobotanical investigation as employed by indians of the Amazon region. The shells of C. acreanum are scraped and placed in warm water about fungal infections. These shells are employed in infusions to combat intestine parasites. And for $C$. spruceanum a shell decoction is used as black scab (caused by arachnids) and the dry shell can be pulverized and applied on fungal infections [30].

To C. spruceanum species, it was found an ethnobotanical and ethnopharmacological investigation of plants used by indians of Peruvian Amazonia against skin infections on shell, fruits and leaves decoction forms [38] [39].

\subsection{Capirona}

\subsubsection{Biological Activity}

It is noteworthy an investigation of the antileishmania activity to $C$. decorticans. The leishmanicide activity in vitro of ethanolic extracts was evaluated for amastigote and promatigotes cultures by the MTT method, obtaining $\mathrm{IC}_{50}>100 \mu \mathrm{g} / \mathrm{mL}$ for both forms, no significant results [40].

\subsubsection{Ethnopharmacological Activity}

The C. decorticans species is also used on formulation of medicines against leishmania by the traditional medicine of ethnic groups on Peruvian Amazonia [34]. It is also used for warts, infected wounds, fungal infections and scabies treatments. The shell is scraped and applied as a cataplasm on the affected area, and the broth of the shell is also used on wounds [40].

\subsection{Chimarrhis}

\subsubsection{Phytochemical Study}

To C. turbunata were stated phytochemical investigations where were isolated and indentified the indolic alkaloid monoterpenic glycosylated strictosidine (10), the derived corinanteans 5 - $\alpha$-carboxystrictosidine (11), isovallesiachotamine (12), vallesiachotamine (13), turbinatine (14), 3,4-dehydro-strictosidine (15), 3,4-dehydrostrictosidine acid (16), strictosidine acid (17), and the alkaloids $\beta$-carbolinic: cordifoline (18), desoxycordifoline (19), and harman-3-carboxylic acid (20) [7] [41] [42] (Figure 3).

Yet for C. turbinata in phytochemical investigations found the flavonoids chimarrhoside (21) quercetin-3-O-rutinoside (22), kaempferol-3-O-rutinoside (23), kaempferol-3-O- $\alpha$-L-rhamnopyranosyl-( $1 \rightarrow 6)-\beta$-D-ga- 
<smiles>C=CC1C(CC2NCCc3c2[nH]c2ccccc32)C(C(=O)OC)CO[C@H]1OC</smiles>

(10)
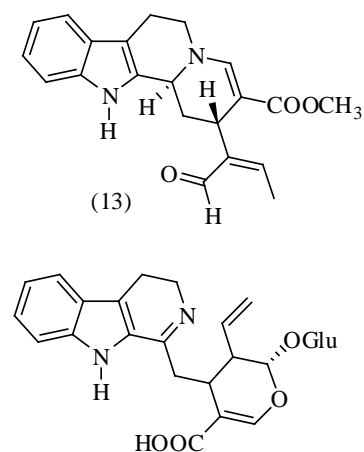

(16)<smiles>C=CC1C(CC2NC(C(=O)O)Cc3c2[nH]c2ccccc32)C(C(=O)O)CO[C@@H]1OC</smiles>

(11)<smiles>C=CC1C(/C(=C/O)C(=O)OC)CC2c3[nH]c4ccccc4c3CCN2C1OC</smiles>

(14)<smiles>C=CC1C(CC2NCCc3c2[nH]c2ccccc32)C(C(=O)O)=CO[C@@H]1OC</smiles>

(17)<smiles>Cc1nc(C(=O)O)cc2c1[nH]c1ccccc12</smiles>

(20)<smiles>C=CC1C(OC)OC=C(C(=O)O)C1Cc1nc(C(=O)O)cc2c1[nH]c1ccccc12</smiles>

(19)<smiles>C/C=C(/C=O)C1CC2c3[nH]c4ccccc4c3CCN2C=C1C(=O)O</smiles><smiles>C=CC1C(CC2=NCCc3c2[nH]c2ccccc32)C(C(C)=O)=CO[C@@H]1OC</smiles>

(15)<smiles>C=CC1C(O)OC=C(C(=O)OC)C1Cc1nc(C(=O)O)cc2c1[nH]c1ccc(O)cc12</smiles>

(18)

Figure 3. Alkaloids isolated of C. turbinata.

lactopyranoside (24), quercetin-3-O- $\alpha$-L-rhamnopyranosyl-( $1 \rightarrow 6)-\beta$-D-galactopyranoside (25), 6-hydro-xy-rutin (26), kaempferol-3-O-D-galactopyranoside (27), kaempferol-3-O-D-glucopyranoside (28), kaempferol-3-O- $\alpha$-L-

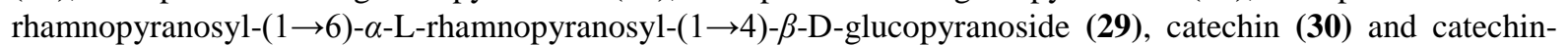
$(4 \alpha \rightarrow 8)$-catechin-procyanidin B-3 (31) [43] (Figure 4).

Also the $C$. turbinata leaves were stated on phytochemical investigations that isolated and identified the derived chlorogenic acid 1-(3',4'-dihydroxycinnamoyl) cyclopentane-2,3-diol (32), trans-chlorogenic acid methyl ester (33) and cis-chlorogenic acid methyl ester (34) and the chimarrhinin (35) [44] [45] (Figure 5).

The C. parviflora species also presented positive results for alkaloids on TLC tests with chromatographic reagents [15].

\subsubsection{Biological Activity}

Special emphasis is given to an investigation of in vitro evaluation of medicines based on C. turbinata by traditional medicine of French Guiana against Plasmodium falciparum, but did not presented significant results, with $\mathrm{IC}_{50}$ upper than $11 \mu \mathrm{g} / \mathrm{mL}$ being considered inactive, and for the test in vivo (suppressive test in four days) the medicines based on C. turbinata did not presented any activity [46].

The isolated compounds (10) to (14) exhibited poor, but selective, activity with values around $\mathrm{IC}_{12}>250$ and $100 \mu \mathrm{g} / \mathrm{mL}$ or more, on mutant yeast strains RS 188N (RAD+) and RS 322YK (rad 52Y), respectively [41] [47].

The compounds (10), (11) and from (14) to (20) were tested for the moiety 1,1-difenil-2-picrilhidrazil (DPPH). The alkaloid (18) presented high scavenging activity to the DPPH radical ( IC $_{50} 18.3 \mu \mathrm{g} / \mathrm{mL}$ ), using the antioxidant rutine pattern ( $\mathrm{IC}_{50} 12.3 \mu \mathrm{g} / \mathrm{mL}$ ) as reference, while all other alkaloids isolated revealed poor activity (IC > $40 \mu \mathrm{M})$. Besides, these alkaloids were submitted to TLC screening for acehylcolinesterase inhibitors. The compounds (14) and (19) revealed moderated inhibition to a concentration of 0.1 and $1.0 \mu \mathrm{M}$, respectively. A trial in vitro with rats' brains (14) presented moderated activity $\left(\mathrm{IC}_{50} 1.86 \mu \mathrm{M}\right)$ compared to the standard compound, galantamine $\left(\mathrm{IC}_{50} 0.92 \mu \mathrm{M}\right)$ [42].

The isolated $C$. turbinata flavonoids were submitted to an antioxidant activity evaluation on DPPH test, using rutine as standard (IC $5021.34 \mu \mathrm{g} / \mathrm{mL}$ ) and BHT (IC $5062.50 \mu \mathrm{g} / \mathrm{mL}$ ). The compounds (22) with $\mathrm{IC}_{50} 21.3 \mu \mathrm{g} / \mathrm{mL}$, 

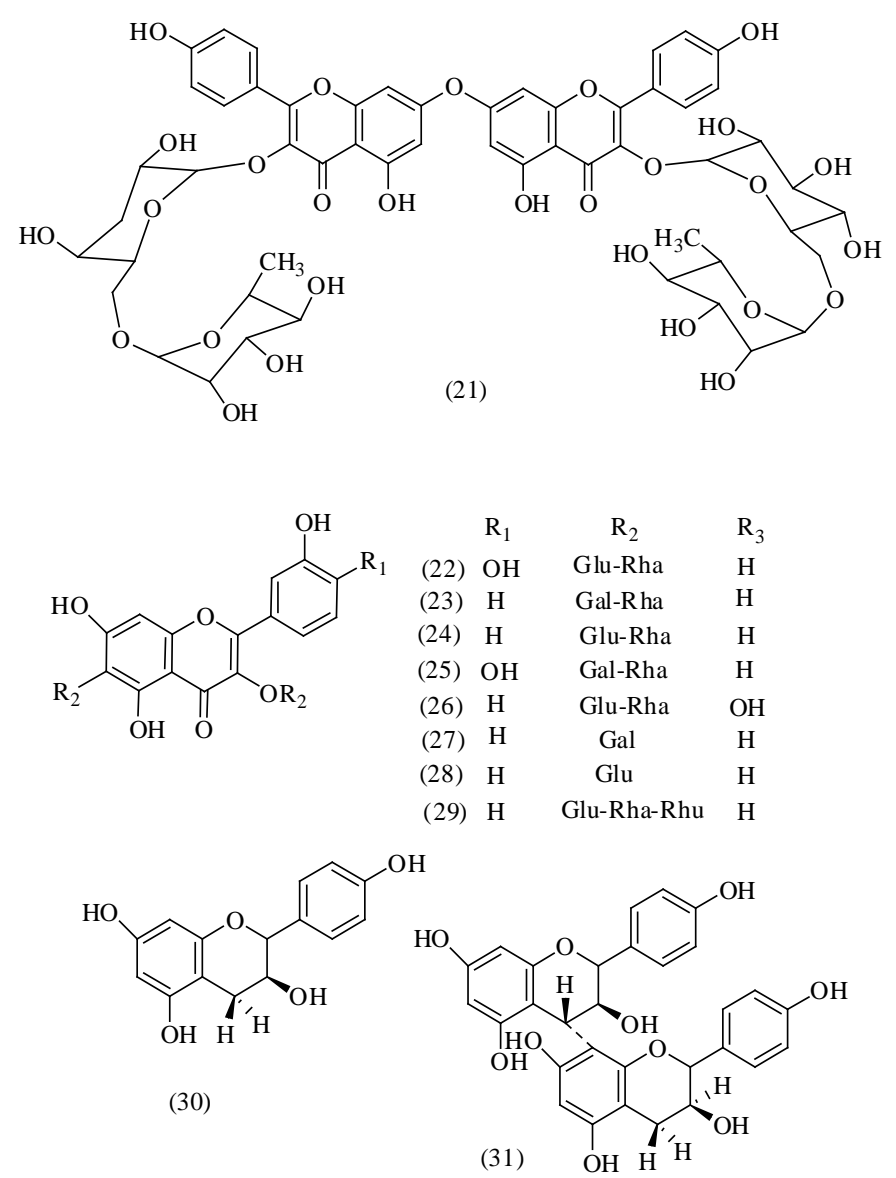

Figure 4. Flavonoid of C. turbinata.<smiles>O=C(/C=C/c1ccc(O)c(O)c1)O[C@H]1CC[C@@H](O)[C@H]1O</smiles>

(32)<smiles>COC(=O)C1(O)C[C@H](O)[C@H](O)[C@H](OC(=O)/C=C\c2ccc(O)c(O)c2)C1</smiles>

(34)<smiles>COC(=O)C1(O)C[C@H](O)[C@H](O)[C@H](OC(=O)/C=C/c2ccc(O)c(O)c2)C1</smiles>

(33)<smiles>O=C(OC1C(C2(c3ccc(O)c(O)c3)CC[C@H](Cc3ccc(O)c(O)c3)C(=O)O2)OC[C@H]1O)c1cc(O)cc(O)c1</smiles>

Figure 5. Other compounds of C. turbinata.

(25) with $\mathrm{IC}_{50} 30.1 \mu \mathrm{g} / \mathrm{mL}$, (26) with $\mathrm{IC}_{50} 25.4 \mu \mathrm{g} / \mathrm{mL}$, (30) with $\mathrm{IC}_{50} 33.4 \mu \mathrm{g} / \mathrm{mL}$, and (31) with $\mathrm{IC}_{50} 11.5$ $\mu \mathrm{g} / \mathrm{mL}$ presented higher activities [43].

The oxidant activity with DPPH of the compounds (33) to (35) were evaluated using as standard the antioxi- 
dant reference BHT (IC $5062.50\left(0.6 \mu \mathrm{mol} \cdot \mathrm{L}^{-1}\right)$ and chlorogenic acid $\left(\mathrm{IC}_{50} 20.0\left(0.2 \mu \mathrm{mol} \cdot \mathrm{L}^{-1}\right)\right.$. The compound (34) revealed the best results with $\mathrm{IC}_{50}$ value $\left(7.50 \pm 0.5 \mu \mathrm{mol} \cdot \mathrm{L}^{-1}\right)$ below the BHT standard. The compounds (33) and (34) revealed $\mathrm{IC}_{50} 18.60 \pm 0.4 \mu \mathrm{mol} \cdot \mathrm{L}^{-1}$ and $\mathrm{IC}_{50} 18.50 \pm 0.6 \mu \mathrm{mol} \cdot \mathrm{L}^{-1}$, respectively. The results indicate the free moiety scavenging activity of these molecules [45].

\subsection{Condaminea}

\subsubsection{Phytochemical Study}

Positive result to Condaminea corymbosa alkaloids on TLC tests with chromatographic reagents with Rubiaceae species at Panama [15].

\subsubsection{Ethnopharmacological Activity}

The ethnopharmacological investigation where is cited the use of C. corymbosa stem as tonic on Peruvian Amazonia traditional medicine is highlighted [48].

\subsection{Dialypetalanthus}

A taxonomical study of $D$. fuscescens species analyzed the composition of polysaccharides on the cell walls of $D$. fuscescens leaves and compared with Bathysa meridionalis. The analyses demonstrated both species have very similar chemical composition of the cell wall corroborating as additional evidence of their taxonomic proximity as is actually accepted [49]. In addition to studies that classify the genus on Ixoroideae subfamily and Condamineeae tribe through molecular phylogenetical investigations [3] [5] [11].

\subsection{Elaeagia}

\subsubsection{Phytochemical Study}

The E. nitidiflora species presented positive results for alkaloids on tests with chromatographic reagents and on this same investigation the E. auriculata species presented negative results [15].

The study in subfraction of ethanol extract obtained from the leaves of E. utilis, analyzed by CG/MS. Terpenes, sesquiterpenlactones and simple phenolic compounds were identified in it for comparison with mass and retention time values from literature (Table 2) [50].

\subsubsection{Biological Activity}

The E. auriculata species activity was also evaluated for against Aphis gossypii and A. craccivora (aphids). The trial was realized on microplates covered by parafilm containing leaves extract $(60 \mu \mathrm{g} / \mathrm{ml})$ and proteins of leaves extract $(33.3 \mu \mathrm{g} / \mathrm{mL})$. The aphids fed up of these extracts on holes in the parafilm. The mortality rate was verified at each 24, 72 and 120 hours and the results were expressed in percentage. The leaves extract of $E$. auriculata presented $29.5 \%$ of mortality rate while the proteins presented $3.7 \%$, no significant results [51].

E. utilis species' antimicrobial activity was evaluated against the bacteria that cause dental caries: Streptococcus mutans, S. sobrinus e Lactobacillus acidophilus. Two extracts, one from light petroleum and an ethanolic one, were obtained from the leaves of $E$. utilis. Both were fractionated and sub-fractionated, according to the presented activities in the evaluation, done by diffusion method in a concentration of $10 \mathrm{mg} /$ well. In each well, $50 \mu \mathrm{l}$ of extract were placed, fraction or sub-fraction, dissolved in DMSO. As a positive control, $50 \mu \mathrm{l}$ of Vancomycin were used with $150 \mu \mathrm{g} / \mathrm{ml}$ concentration and $50 \mu \mathrm{l}$ of DMSO as negative control. After $24 \mathrm{~h}$ of incubation, the inhibition zones were measured and, the minimum inhibitory concentration, calculated (MIC; at least 6

\begin{tabular}{|c|c|}
\hline \multicolumn{2}{|c|}{ Compounds in E. utilis } \\
\hline Benzyl alcohol & 3-methoxy-4-hydroxybenzaldehyde \\
\hline Benzoic acid & 4-vinylphenol \\
\hline Benzoic acid, 2-hydroxy-, phenyl methyl ester & 2,5-dimethyl-(3-methoxymethyl)-p-benzoquinone \\
\hline 2,3-dihydrobenzofuran & 1,Z-5,E-7-dodecatrien \\
\hline 4-((1e)-3-hydroxy-1-propenyl)-2-methoxyphenol2 & 2,6-dimethoxy-4-(2-propenyl) phenol \\
\hline -methoxy-4-vinylphenol & Loliolide \\
\hline
\end{tabular}


$\mathrm{mm})$. Between the ethanolic extract fractions, the fraction of dichloromethane presented the greatest level of activity, being sub-fractionated in three fractions, of which the $\mathrm{MeOH}: \mathrm{H}_{2} \mathrm{O}$ fraction presented MIC $=0.1 \mu \mathrm{g} /$ well with three tested bacteria. In this fraction, the presence of terpenes, sesquiterpenlactones and phenolic compounds, was confirmed through phytochemical tests, suggesting the relation between these compounds and the presented activity [50].

\subsection{Emmenopterys}

\subsubsection{Phytochemical Study}

Special emphasis is given to the phytochemical investigations for $E$. henryi reporting the isolation and investigation of cumarins: scopoletin (36), umbelliferone (37) and umbelliferone-7- $\beta$-D-glucoside (38); the steroids: $\beta$-sitosterol (39) and 3-O- $\beta$-D-glucopyranosylsitosterol (40); the ursane triterpenes: taraxerol (41), taraxerone

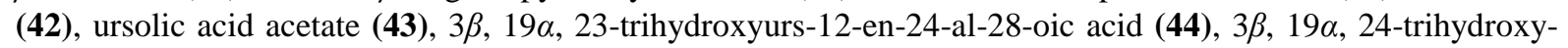
23-norurs-12-en-28-oic acid (45), $12 \beta$-hydroxy-5 $\alpha$-pregnane-14.16-dien-3.20-dione (46), pomolic acid (47), $3 \beta$,

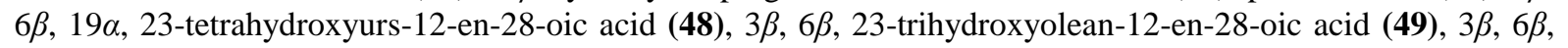
$19 \alpha$, 23-tetrahydroxyolean-12-en-28-oic acid (50) and 3 $\beta$, 23.24-trihydroxyolean-12-en-28-oic acid (51); and the pregnanes derivatives: $3 \beta, 12 \beta$-dihydroxy- $5 \alpha$-pregnane-14.16-dien-20-one (52), $12 \beta$-hydroxy-5 $\alpha$-pregnane-14, 16-dien-3.20-dione (53), 3 $\beta, 12 \beta$-dihydroxy- $5 \alpha$-pregnane-16-en-20-one (54) and $12 \beta$-dihydroxy-5 $\alpha$-pregnane16-en-3.20-dione (55) [52] [53] (Figure 6).

\subsubsection{Biological Activity}

The petroleum ether extract of the E. henryi stem presented antifeedant activity against Plutella xylostella on larvae trial treatment. The extract presented $80.09 \%$ of mortality rate against Plutella xylostella and $62.80 \%$ against Spodoptera litura, indicating high activity compared to industrially marketed standards on China and suggests further investigations for the use of this species as an insecticide [54].

\subsection{Hippotis}

In addition to studies which classify the genus on Ixoroideae subfamily and Condamineeae tribe through molecular phylogenetic investigations [3] [11], it was found only one ethnopharmacological study suggesting the $H$. tubiflora stem is used as tonic on Peruvian Amazonia traditional medicine [48].

\subsection{Macrocnemum}

\subsubsection{Biological Activity}

Evaluation of $M$. roseum leaves and bracts ethanolic extracts against leishmania using MTT method to determine the extract activities. For bioassays the extracts were dissolved on DMSO (final concentration 1\%) at 10 $\mathrm{mg} / \mathrm{mL}$ concentration, presenting moderate activity with $\mathrm{IC}_{50} 37 \mathrm{~g} / \mathrm{mL}$ to bracts extract and $\mathrm{IC}_{50} 22 \mathrm{~g} / \mathrm{mL}$ to leaves extract [34].

\subsubsection{Ethnopharmacological Activity}

An investigation of $M$. roseum states the use of leaves to treat wounds on traditional medicine of Peru. The leaves are boiled on water and the wounds washed the same water, but cold [34] [55].

\subsection{Pentagonia}

\subsubsection{Phytochemical Study}

It is noteworthy a phytochemical investigation with $P$. gigantifolia root ethanolic extracts where were isolated the compounds: 6-octadecynoic acid (56) and 6-nonadecynoic acid (57) [56] (Figure 7).

\subsubsection{Biological Activity}

The investigation with P. gigantifolia root ethanolic extract presented antifungal activity against Candida albicans, with $\mathrm{IC}_{50}<20 \mu \mathrm{g} / \mathrm{mL}$. Susceptibility tests to antifungal agents were realized using a modified version of NCCLS methods. After being chromatographed one of the fractions was tested and presented the highest activity with $\mathrm{IC}_{50}<2 \mu \mathrm{g} / \mathrm{mL}$ [56]. 

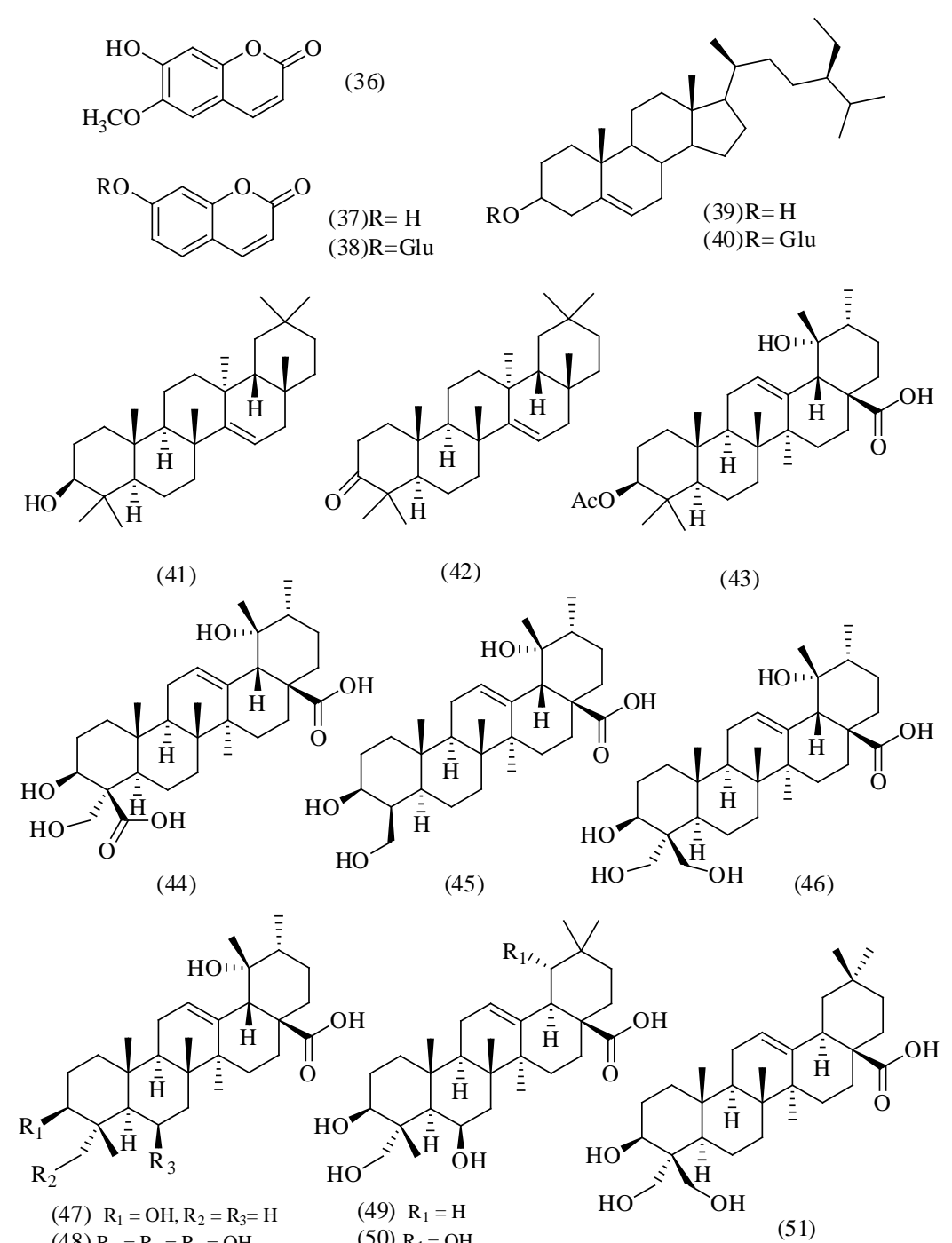

$\begin{array}{lll}(48) R_{1}=R_{2}=R_{3}=\mathrm{OH} & \text { (50) } \mathrm{R}_{1}=\mathrm{OH}\end{array}$<smiles>CC(=O)C1=CC=C2[C@@H]3CC[C@H]4C[C@@H](O)CC[C@]4(C)[C@H]3C[C@H](O)[C@]12C</smiles>

(52)

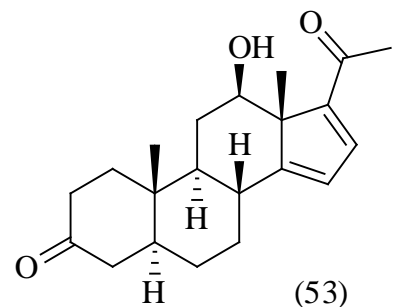

(53)<smiles>CC(=O)C1=CC[C@H]2[C@@H]3CC[C@H]4C[C@@H](O)CC[C@]4(C)[C@H]3C[C@H](O)[C@]12C</smiles>

(54)

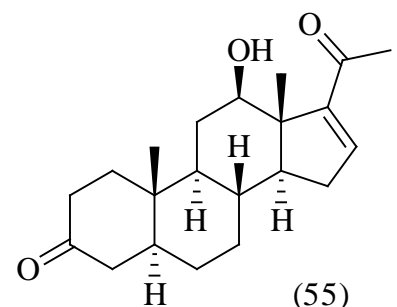

(55)

Figure 6. Compounds isolated from E. henryi. 


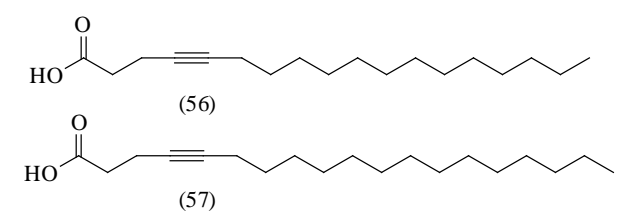

Figure 7. Fatty acids of Pentagonia gigantifolia.

The evaluation of compounds (56) with $\mathrm{IC}_{50}$ range of 0.45 to $0.65 \mu \mathrm{g} / \mathrm{mL}$ and (57) with $\mathrm{IC}_{50}$ range of 0.25 to $0.45 \mu \mathrm{g} / \mathrm{mL}$ presented activity with many C. albicans strains [56].

\subsubsection{Ethnopharmacological Activity}

It was found a study that states the use of $P$. pubens shell boiled on water to combat malaria and also it use as ornamental plant [57].

\subsection{Pogonopus}

\subsubsection{Phytochemical Study}

Phytochemical study of $P$. specious branches extracts led to the isolation of the alkaloids 1', 2', 3', 4'-tetradehydrotubulosine (58), tubulosine (59) and psychotrine (60) [58]. The phytochemical investigation of $P$. tubulosus branches extracts, besides the compounds (59) and (60), the alkaloid cephaeline (61) was also isolated [59] (Figure 8).

\subsubsection{Biological Activity}

On cytotoxicity trial the $P$. tubulosus extract obtained by acid-base extraction revealed $\mathrm{IC}_{50}=0.015 \mu \mathrm{g} / \mathrm{mL}$ against epidermoid carcinoma KB cells in culture. The (58) and (59) alkaloids were evaluated against several human tumor cell lines presenting poor cytotoxicity with $\mathrm{ED}_{50}=2.2$ to $9.0 \mu \mathrm{g} / \mathrm{mL}$ for (58) and $\mathrm{ED}_{50}=2.3$ to $13.3 \mu \mathrm{g} / \mathrm{mL}$ for (60), activity considered poor compared to the most potent activity observed for tubulosine (59), with $\mathrm{ED}_{50}<0.001$ to $0.22 \mu \mathrm{g} / \mathrm{mL}$ [58].

The raw ethanolic extract and a $P$. tubulosus extract obtained by acid-base extraction were also evaluated for antiproliferative activity against several lines of human neoplastic cells: ATCC-CCL-23, laryngeal carcinoma, ATCC-HTB-22, breast carcinoma, ATCC-CRL-1932, liver carcinoma, ATCC-HTB-38, colon carcinoma, and murine cancer: ATCC-CRL-6322, murine melanoma. The raw extract presented IC $_{100}$ range of 2.2 to $6.9 \mu \mathrm{g} / \mathrm{mL}$ and the extract of acid-base extraction with $\mathrm{IC}_{100}$ range of 0.24 to $2.2 \mu \mathrm{g} / \mathrm{mL}$ presented high antiproliferative activity against all neoplastic cells lines [60].

The alkaloids (59), (60) and (61) were also tested against sensible strains and resistant to Plasmodium falsiparumin vitro and against $P$. berghei and $P$. vinckei petteri (in vivo). Tubulosine (59) presented in vitro $\mathrm{IC}_{50}=$ $0.006 \mu \mathrm{g} / \mathrm{mL}$ against sensible $P$. falciparum and $\mathrm{IC}_{50}=0.011 \mu \mathrm{g} / \mathrm{mL}$ against resistant $P$. falciparum. And in vivo presented antimalarial activity with $\mathrm{ED}_{50}=0.05 \mathrm{mg} / \mathrm{Kg} /$ day for $P$. vinckei petteri and $\mathrm{ED}_{50}=0.45 \mathrm{mg} / \mathrm{Kg} / \mathrm{day}$ for $P$. berghei against Plasmodium falciparum in vitro tests. The in vivo tests were done through the classic suppression method during four days [59] [61].

The psychotrine alkaloid (60) presented in vitro $\mathrm{IC}_{50}=0.14 \mu \mathrm{g} / \mathrm{mL}$ against sensible $P$. falciparum and $\mathrm{IC}_{50}=$ $0.39 \mu \mathrm{g} / \mathrm{mL}$ against resistant $P$. falciparum. And in vivo presented antimalarial activity with $\mathrm{ED}_{50}>2 \mathrm{mg} / \mathrm{Kg} /$ day for $P$. berghei. The cefaeline alkaloid (61) presented in vitro $\mathrm{IC}_{50}=0.027 \mu \mathrm{g} / \mathrm{mL}$ against sensible $P$. falciparum and $\mathrm{IC}_{50}=0.011 \mu \mathrm{g} / \mathrm{mL}$ against resistant $P$. falciparum. And in vivo presented antimalarical activity with $\mathrm{ED}_{50}=6 \mathrm{mg} / \mathrm{Kg} /$ day for $P$. berghei [59].

\subsubsection{Ethnopharmacological Activity}

Studies of the use of $P$. tubulosus on traditional medicine of Bolivia against malaria in the stem bark decoction form [62].

\subsection{Rustia}

\subsubsection{Phytochhemical Study}

The study of essential oil extracted from Rustia formosa secretory cavities, analyzed by CG/MS, presented a 


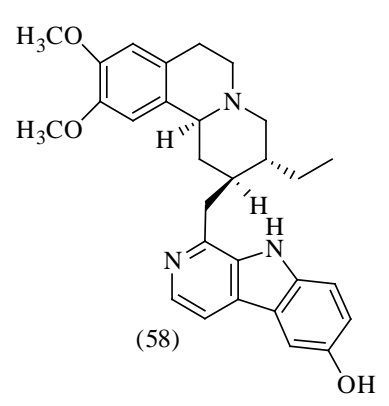<smiles>CC[C@H]1CN2CCc3cc(OC)c(OC)cc3[C@@H]2C[C@H]1C[C@H]1NCCc2c1[nH]c1ccc(O)cc21</smiles><smiles>CC[C@H]1CN2CCc3cc(OC)c(OC)cc3[C@H]2C[C@H]1CC1=NCCc2cc(O)c(OC)cc21</smiles><smiles>CC[C@H]1CN2CCc3cc(OC)c(OC)cc3[C@H]2C[C@H]1CC1NCCc2cc(O)c(O)cc21</smiles>

(61)

Figure 8. Alkaloids Isolated of Pogonopus genus.

complex mix of 75 terpenic components, formed mainly by sesquiterpens, substances solely identified for comparison with mass and retention time values from literature (Table 3) [63].

\subsubsection{Ethnopharmacological Activity}

An investigation states the use of $R$. formosa species on Brazilian traditional medicine as substitute of Chinchona spp., based on pharmacological studies [18].

\subsection{Sommera}

\subsubsection{Phytochemical Study}

The phytochemical investigation of $S$. sabiceoides roots ethanolic extracts presented five fatty acids: 6-hexadecynoic acid (62), 6-heptadecynoic acid (63) and 6-icosynoic acid (64) (Figure 9) and 6-octadecynoic acid (56) and 6-nonadecynoic acid (57) [63] (Figure 7).

\subsubsection{Biological Activity}

The S. sabiceoides dichloromethane extract presented 96\% of inhibition against Mycobacterium tuberculosis, in $50 \mu \mathrm{g} / \mathrm{mL}$ and presented MIC $<6.25 \mu \mathrm{g} / \mathrm{mL}$, considered excellent results. The in vitro experiments (trials) were done using a radiometric detector semiautomized to monitor the Mycobacterium tuberculosis growth [36].

The methanolic extract tested against Candida albicans presented 50\% inhibition with $\mathrm{IC}_{50}<20 \mu \mathrm{g} / \mathrm{mL}$. The in vitro cytotoxocity was determined by the neutral red method. On the in vivo cytotoxicity experiment the compounds were dissolved on peanut oil until the desired concentration. Six rat groups received $100 \mu \mathrm{L}$ intraperitoneal injections, providing compound doses of 3, 4, 17 or $34 \mu \mathrm{mol} / \mathrm{kg}$ of body weight.

The S. sabiceoides compounds (56) and (57) presented positive results against Trichophyton mentagrophytes ATCC MYA-4439, T. mentagrophytes ATCC 9533, T. rubrum ATCC 10218, and T. rubrum ATCC MYA-4438 presenting MFC range from 0.7 to $11.1 \mu \mathrm{M}$. The S. sabiceoides compounds (62) and (64) along with (56) and (57) were also active against Candida krusei ATCC 6258 with MIC range from 4.4 to $10.6 \mathrm{Mm}$ [64].

The compound (57) also presented activity against C. albicans (MIC range from 1.3 to $8.0 \mu \mathrm{M}$ ) against Aspergillus fumigatus (MIC range from 2.7 to $6.6 \mu \mathrm{M}$ ), against T. mentagrophytes e T. rubrum strains (MIC range from 0.7 to $3.3 \mu \mathrm{M}$ ) and against fluconazol-resistant C. albicans (MIC range from 1.3 to $8.0 \mu \mathrm{M}$ ).

The compounds (62) and (64) did not presented in vitro toxicity to concentrations until $32 \mu \mathrm{M}$ on cytotoxicity test with SK-MEL cells (melanoma), KB (epidermic carcinoma, oral), BT-549 (ductal carcinoma, breast), SK-OV-3 (ovary carcinoma), and LLCPK-1 (pork kidney epithelial). And on cytotoxicity test (56) and (57) did not presented toxic effects on doses less than $34 \mu \mathrm{mol} / \mathrm{Kg} /$ day [64]. 


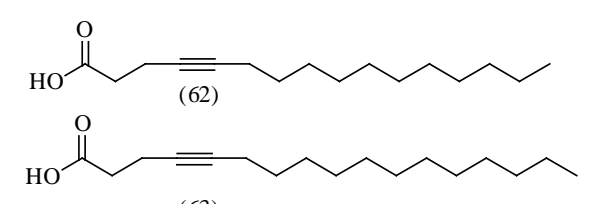

(63)

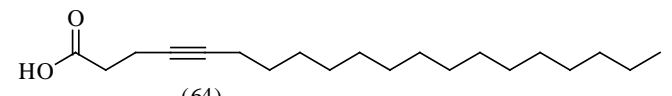

(64)

Figure 9. Fatty acids of Sommera sabiceoides.

Table 3. Compounds identified in $R$. formosa essential oil.

\begin{tabular}{llllll}
\hline \multicolumn{5}{c}{ Compounds in $R$. formosa essential oil } \\
\hline$\beta$-elemene & germacrene D & $\alpha$-humulene & $\alpha$-muurolene & curzerenone & germacrene B \\
$\gamma$-muurolene & $\gamma$-elemene & cis- $\beta$-guaiene & caryophylleneoxide & $\alpha$-cadinene & epi- $\alpha$-muurolol \\
$\beta$-caryophyllene & $\beta$-selinene & $\alpha$-cadinol & $\delta$-cadinene & epi- $\alpha$-cadinol & germacrone \\
\hline
\end{tabular}

\subsection{Warszewiczia}

\subsubsection{Phytochemical Study}

The W. coccinea shell was tested on a histochemical study for alkaloid presence, presenting negative result [65], however presented positive results on another investigation regarding chromatographic techniques [15].

Still, $W$. coccinea investigations stated the presence of the triterpens $3 \beta, 6 \beta, 19 \alpha$-trihydroxy-urs-12-en-28-oic acid (65) and 3 $\beta$, 6 $\beta$-dihydroxy-olean-12-en-28-oic acid (66) [23] and the tiramine methabolites (67) and cyanidin 3-glicoside (68) [66] (Figure 10).

\subsubsection{Biological Activities}

Evaluation of $W$. cordata antileishmania activity. The experiments were conducted on promastigotes and axenic amastigotes of Leishmania amazonensis and the extract activity was determined through MTT method. The $W$. cordata branches ethanolic extract presented $\mathrm{IC}_{50}=60.6 \mu \mathrm{g} / \mathrm{ml}$ for the amastigote form, moderated activity, presented no result for promastigote form [67].

An investigation of the $W$. coccinea ethanolic extract activity against leishmania (Leishmania amazonensis) revealed poor activity determined through MTT method, presenting $\mathrm{IC}_{50}>100 \mu \mathrm{g} / \mathrm{mL}$ to shell extract and $\mathrm{IC}_{50}=$ $54.3 \mu \mathrm{g} / \mathrm{mL}$ to branches extract. To the antimalaric (Plasmodium falciparum FCR3 in vitro) there was no activity [68].

The $W$. coccinea stem extract strongly inhibited acetylcholinesterase in $100 \mu \mathrm{g}$ on TLC, and inhibited poorly free DPPH moieties on antioxidant test. On the same investigation the compounds (65) and (66) were active on the inhibition acetylcholinesterase test with $1 \mu \mathrm{g}$ at each TLC plate [23].

\subsubsection{Ethnopharmacological Activity}

An ethnobotanic investigation stated the use of $W$. coccinea grated shell in cold water intake for convulsion and epilepsy treatment on Peruvian traditional medicine [68].

There were also found ethnobotanic investigations wherein the $W$. coccinea roots are dried and the powder is applied with oil to fungal skin disorders or the root is boiled and applied as decoction to pain relief [30].

$W$. coccinea shells are also used as haemostatic by Colombian indians, to nosebleed treatment at Peru and fever at Porto Rico [23].

The Dioicodendron, Dolichodelphys, Dolicholobium, Ferdinandusa, Holtonia, Macbrideina, Mastixiodendron, Mussaendopsis, Parachimarrhis, Picardaea, Pinckneya, Schizocalyx, Semaphyllanthe, Tammsia e Wittmackanthus genus presented absence or irrelevant investigations to this review.

\section{Results and Discussion}

In relation to the phytochemical studies, from the 33 genus in the Condamineeae Tribe, approximately 13 presented at least one studied species, containing isolated or identified secondary metabolites. In a total of 110 


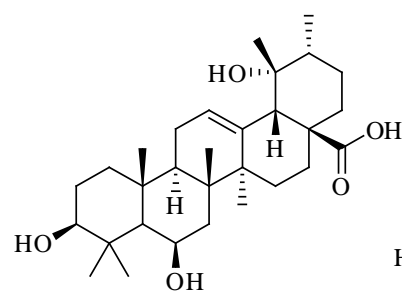

(65)

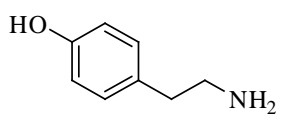

(67)

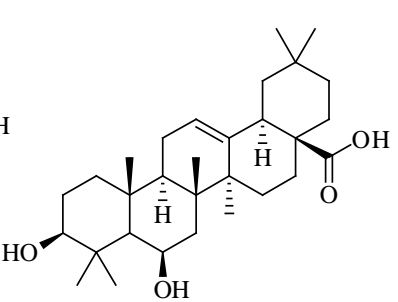

(66)

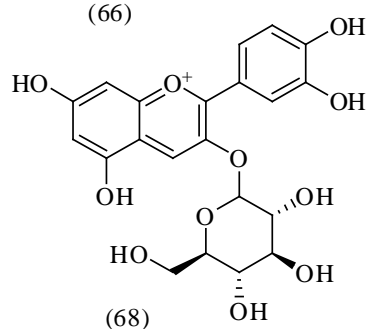

Figure 10. Compounds isolated of $W$. coccinea.

isolated and identified substances in these species, including the results of the review for the genus Simira [14], approximately $24.54 \%$ were from the alkaloid's class, and from these substances, approximately $81.18 \%$ are indole alkaloids, which are considered as chemotaxonomic markers from family [7]. The class of terpenoids metabolites, including diterpens, triterpens, and steroids, presents a bigger percentage, approximately $27.27 \%$ of the substances found in this tribe until this moment (Graphic 1 and Graphic 2)

According to the biological activity, from the 33 genus in the tribe, 13 presented some evaluation of biological activity, and 14 presented reports of ethnopharmacological application, but not necessarily showed biological activity.

From the 13 genus which presented biological activity, 9 genus, including the genus Simira, presented studies reporting the presence of alkaloid or a positive result when tested for alkaloids. And from these 9 genus, 7 also presented ethnopharmacological reports (Graphic 3 and Graphic 4).

\section{Conclusions}

It was observed the species that belongs to the genera of Condamineeae tribe presented a considered number of metabolites in similar biosynthetic origin and a lot of them presenting some kind of biological activity.

The alkaloids found for Simira genus are indolic [14] as the alkaloids presented for Chimarrhis and Pogonopus genus, considered as taxonomic markers of the family, belongs to the most investigated secondary metabolic groups aiming to prove the phyologenetic correlation between Ruibiaceae chemistry and taxonomy. Evidences based on indolic alkaloids skeletons, used for chemical and morphological evolutionary comparisons between Rubiaceae, Apocynaceae and Loganiaceae [8].

The presence of iridoids and it derivatives secoirioids of Calycophyllum genus also demonstrates the connection between the genus presenting monoterpenes indolic alkaloids, as Chimarrhis and Pogonopus, since the secoiridoids are involved on the construction of the basic skeleton of indolic alkaloids [69]. This proximity relationship can extend to the genus that presented positive results for alkaloids on chromatographic tests as Alseis, Bathysa, Condaminea, Elaeagia, Macrocnemum, Pentagonia, Rustia, Sommera, Warszewiczia e também o gênero Simira. The Calycophyllum genus presented positive results for alkaloids.

For Chimarrhis genus it was found the harman-3-carboxilic acid (20) (Figure 3), structure that could derive from harmana alkaloid, considered as a taxonomic tracer in Simira genus [14] corroborating the proximity between the Simira and Chimarrhis genus.

This review also states the scarcity of phytochemical investigations of several genera and consequently a lot of species of Rubiaceae family. It could contribute more significantly to this family taxonomy.

\section{Acknowledgements}

The authors are thankful to CNPq and FAPERJ for financial support. 


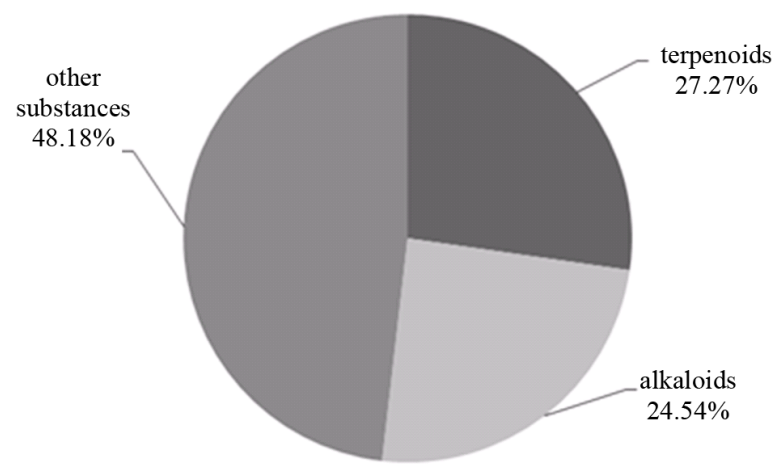

Graphic 1. Percentage of the compounds isolated in Condamineeae tribe.

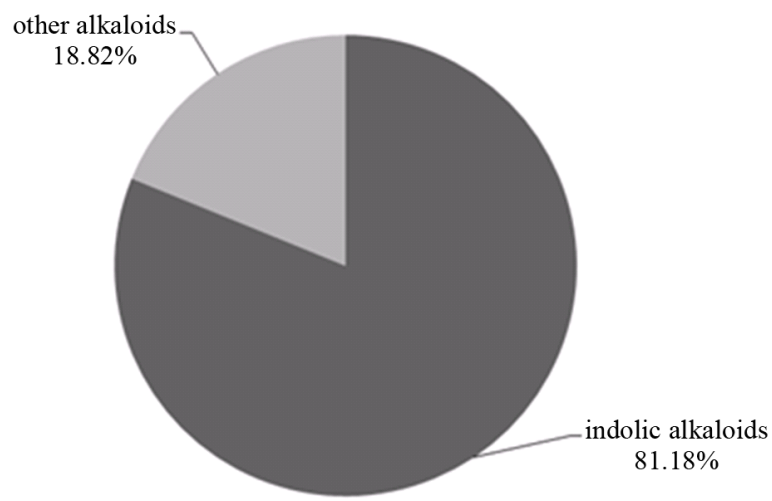

Graphic 2. Percentage of alkaloids isolated in Condamineeae tribe.

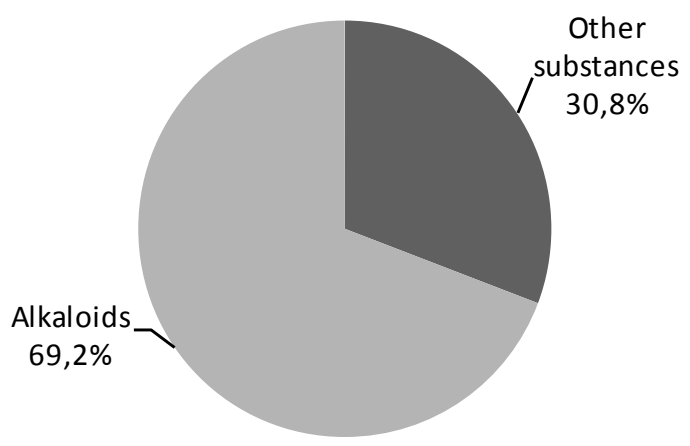

Graphic 3. Alkaloids percentage in genus with biological activity.

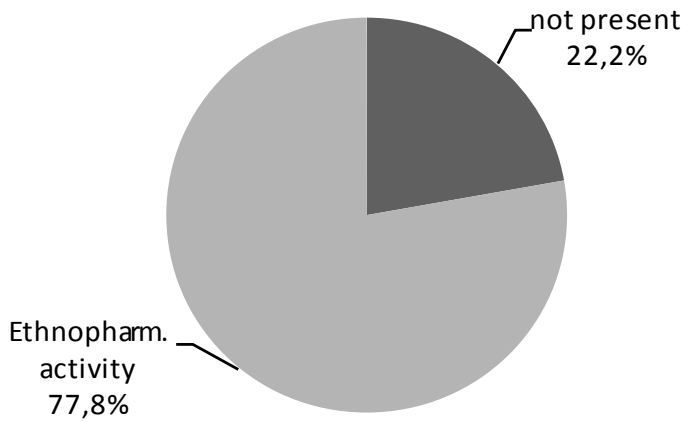

Graphic 4. Ethnopharmacological activity percentage in genus with alkaloids. 


\section{Conflict of Interest}

The authors confirm that this article content has no conflict of interest.

\section{References}

[1] Robbrecht, E. and Manen, J. (2006) The Major Evolutionary Lineages of the Coffee Family (Rubiaceae, Angiosperms). Combined Analysis (nDNA and cpDNA) to Infer the Position of Coptosapelta and Luculia, and Supertree Construction Based on $r b c L$, rps16, trnL-trnF and $a t p B-r b c L$ Data. A New Classification in Two Subfamilies, Cinchonoideae and Rubioideae. Systematics and Geography of Plants, 76, 85-146.

[2] Bremer, B., Jansen, R.K., Oxelman, B., Backlund, M., Lantz, H. and Kim, K.J. (1999) More Characters and More Taxa for a Robust Phylogeny-Case Study from the Coffee Family (Rubiaceae). Systematic Biology, 48, 413-435. http://dx.doi.org/10.1080/106351599260085

[3] Rova, J.H.E., Delprete, P.G., Andersson, L. and Albert, V.A. (2002) A trnL-F cpDNA Sequence Study of the Condamineeae-Rondeletieae-Sipaneeae Complex with Implications on the Phylogeny of the Rubiaceae. American Journal of Botany, 89, 145-159. http://dx.doi.org/10.3732/ajb.89.1.145

[4] Judd, W.S., Campbell, C.S., Kellogg, E.A. and Stevens, P.F. (2007) Plant Systematics: A Phylogenetic Approach. 3rd Edition, Sinauer Associates, Inc., Sunderland.

[5] Delprete, P.G. (1999) Rondeletieae (Rubiaceae)_Part I (Rustia, Tresanthera, Condaminea, Picardaea, Pogonopus, Chimarrhis, Dioicodendron, Molopanthera, Dolichodelphys, and Parachimarrhis). Flora Neotropica Monograph, Vol. 77, 1-226.

[6] Barbosa, M.R. Simira in List of Species of Flora of Brazil. Botanical Garden of Rio de Janeiro. Accessed 30 March 2014. http://floradobrasil.jbrj.gov.br/jabot/floradobrasil/FB14287

[7] Cardoso, C.L., Silva, D.H.S., Young, M.C.M., Castro-Gamboa, I. and da Silva Bolzani, V. (2008) Indole Monoterpene Alkaloids from Chimarrhis turbinata DC Prodr.: A Contribution to the Chemotaxonomic Studies of the Rubiaceae Family. Brazilian Journal of Pharmacognosy, 18, 26-29. http://dx.doi.org/10.1590/s0102-695x2008000100007

[8] Bolzani, V.S., Yong, M.C.M., Furlan, M., Cavalheiro, A.J., Araujo, A.R., Silva, D.H.S. and Lopes, M.N. (2001) Secondary Metabolites from Brazilian Rubiaceae Plant Species: Chemotaxonomical and Biological Significance. Recent Research Developments in Phytochemistry, 5, 19-31.

[9] Bremer, B. and Eriksson, O. (2009) Time Tree of Rubiaceae: Phylogeny and Dating the Family, Subfamily, and Tribes. International Journal of Plant Science, 170, 766-793. http://dx.doi.org/10.1086/599077

[10] Bremer, B. (2009) A Review of Molecular Phylogenetic Studies of Rubiaceae. Annals of the Missouri Botanical Garden, 96, 4-26. http://dx.doi.org/10.3417/2006197

[11] Kainulainen, K., Persson, C., Eriksson, T. and Bremer, B. (2010) Molecular Systematics and Morphological Character Evolution of the Condamineeae (Rubiaceae). American Journal of Botany, 97, 1961-1981. http://dx.doi.org/10.3732/ajb.1000090

[12] Razafimandimbison, S.G. and Bremer, B. (2001) Tribal Delimitation of Nuclease (Cinchonoideae, Rubiaceae): Inference from Molecular and Morphological Data. Systematics and Geography of Plants, 71, 515-538. http://dx.doi.org/10.2307/3668697

[13] Fay, M.F., Bremer, B., Prance, G.T., van der Bank, M., Bridson, D. and Chase, M.W. (2000) Plastid rbcL Sequence Data Show Dialypetalanthus to Be a Member of Rubiaceae. Kew Bulletin, 55, 853-864. http://dx.doi.org/10.2307/4113630

[14] Moreira, V.F., Vieira, I.J.C. and Braz-Filho, R. (2014) Chemical Constituents and Biological Activities of Simira Genus: A Contribution to the Chemotaxonomic of Rubiaceae Family. The Natural Products Journal, 4, 290-298. http://dx.doi.org/10.2174/2210315505666141211225600

[15] Soto-Sobenis, A., Castillo, B., Delgado, A., González, A. and Montenegro R. (2001) Alkaloid Screening of Herbarium Samples of Rubiaceae from Panama. Pharmaceutical Biology, 39, 161-169. http://dx.doi.org/10.1076/phbi.39.3.161.5925

[16] Slish, D.F., Arvigo, R. and Balick, M.J. (2004) Alseis yucatanensis: A Natural Product from Belize That Exhibits Multiple Mechanisms of Vasorelaxation. Journal of Ethnopharmacology, 92, 297-302. http://dx.doi.org/10.1016/j.jep.2004.03.003

[17] Slish, D.F., Ueda, H., Arvigo, R. and Balick, M.J. (1999) Ethnobotany in the Search for Vasoactive Herbal Medicines. Journal of Ethnopharmacology, 66, 159-165. http://dx.doi.org/10.1016/S0378-8741(98)00225-6

[18] Cosenza, G.P., Somavilla, N.S., Fagg, C.W. and Brandão, M.G.L. (2013) Bitter Plants Used as Substitute of Cinchona spp. (Quina) in Brazilian Traditional Medicine. Journal of Ethnopharmacology, 149, 790-796. http://dx.doi.org/10.1016/j.jep.2013.08.004 
[19] Weeks, R.A., Dobberstein, R.H. and Farnsworth, N.R. (1977) Isolation of Paeonol from Bathysa meridionalis. Lloydia, 40, 515-516.

[20] Rangel, L.P., de Abreu, L.F., de Andrade, A.R., Leitão, S.G., Leitão, G.G. and Ferreira-Pereira, A. (2008) Effect of Different Extracts from the Brazilian Atlantic Forest on the Pdr5p ATPase Activity. Brazilian Journal of Pharmacognosy, 18, 30-36. http://dx.doi.org/10.1590/s0102-695x2008000100008

[21] Gontijo, D.C., Nunes, L.G., Souza, C.J.A., Fietto, L.G. and Leite, J.P.V. (2012) Evaluation of the Genotoxic Potential of Ethanolic Extracts of Stem Bark and Leaves of Bathysa cuspidata (A.St.-Hil.) Hook. Revista de Ciências Farmacêuticas Básica e Aplicada, 33, 355-359.

[22] Novaes, R.D., Gonçalves, R.V., Marques, D.C.S., Cupertino, M.C., Peluzio, M.C.G., Neves, C.A., Leite, J.P.V. and Maldonado, I.R.S.C. (2012) Effect of Bark Extract of Bathysa cuspidata on Hepatic Oxidative Damage and Blood Glucose Kinetics in Rats Exposed to Paraquat. Toxicologic Pathology, 40, 62-70. http://dx.doi.org/10.1177/0192623311425059

[23] Calderón, A.I., Simithy, J., Quaggio, G., Espinosa, A., López-Pérez, J.L. and Gupta, M.P. (2009) Triterpenes from Warszewiczia coccinea (Rubiaceae) as Inhibitors of Acetylcholinesterase. Natural Product Communications, 4, 13231326.

[24] de Castro Miguel, E., Gomes, V.M., de Oliveira, M.A. and da Cunha, M. (2006) Colleters in Bathysa nicholsonii K. Schum. (Rubiaceae): Ultrastructure, Secretion Protein Composition, and Antifungal Activity. Plant Biology, 8, 715722. http://dx.doi.org/10.1055/s-2006-924174

[25] Fonseca, T.L., Von Groll, A., Leitão, G.G., Scaini, C.J., Ramos, D.F. and Silva, P.E.A. (2008) Antimycobacterial Vegetal Extracts against Mycobacterium fortuitum and Mycobacterium malmoense. Vittalle, 20, 65-71.

[26] Carvalho, D.D.C., Alves, E., Camargos, R.B., Oliveira, D.F., Scolforo, J.R.S., de Carvalho, D.A. and Batista, T.R.S. (2011) Plant Extracts to Control Alternaria alternata in Murcott Tangor Fruits. Revista Iberoamericana de Micología, 28, 173-178. http://dx.doi.org/10.1016/j.riam.2011.05.001

[27] Novaes, R.D., Gonçalves, R.V., Cupertino, M.C., Marques, D.C.S., Rosa, D.D., Peluzio, M.C.G., Neves, C.A. and Leite, J.P.V. (2012) Bark Extract of Bathysa cuspidata Attenuates Extra-Pulmonary Acute Lung Injury Induced by Paraquat and Reduces Mortality in Rats. International Journal of Experimental Pathology, 93, 225-233. http://dx.doi.org/10.1111/j.1365-2613.2012.00808.x

[28] Gonçalves, R.V., Novaes, R.D., Leite, J.P.V., Vilela, E.F., Cupertino, M.C., Nunes, L.G. and Matta, S.L.P. (2012) Hepatoprotective Effect of Bathysa cuspidata in a Murine Model of Severe Toxic Liver Injury. International Journal of Experimental Pathology, 93, 370-376. http://dx.doi.org/10.1111/j.1365-2613.2012.00835.X

[29] Gonçalves, R.V., Novaes, R.D., Cupertino, M.C., Araújo, B.M., Vilela, E.F., Machado, A.T., Leite, J.P.V. and Matta, S.L.P. (2014) Bathysa cuspidata Extract Modulates the Morphological Reorganization of the Scar Tissue and Accelerates Skin Wound Healing in Rats: A Time-Dependent Study. Cells Tissues Organs, 199, 266-277. http://dx.doi.org/10.1159/000365504

[30] Schultes, R.E. (1985) De Plantis Toxicariis e Mundo Novo Tropicale Commentationes XXXIV: Biodynamic Rubiaceous Plants of the Northwest Amazon. Journal of Ethnopharmacology, 14, 105-124. http://dx.doi.org/10.1016/0378-8741(85)90082-0

[31] Saenz, R., Nassar, J.A. and Maryssia, C. (1965) Phytochemical Screening of Costa Rican Plants: Alkaloid Analysis II. Revista de Biologia Tropical, 13, 207-212.

[32] Zuleta, L.M.C., Cavalheiro, A.J., Silva, D.H.S., Furlan, M., Young, M.C.M., Albuquerque, S., Castro-Gamboa, I. and da Silva Bolzani, V. (2003) seco-Iridoids from Calycophyllum spruceanum (Rubiaceae). Phytochemistry, 64, 549-553. http://dx.doi.org/10.1016/S0031-9422(03)00153-5

[33] Portillo, A., Vila, R., Freixa, B., Adzet, T. and Cañigueral, S. (2001) Antifungal Activity of Paraguayan Plants Used in Traditional Medicine. Journal of Ethnopharmacology, 76, 93-98. http://dx.doi.org/10.1016/S0378-8741(01)00214-8

[34] Odonne, G., Bourdy, G., Castillo, D., Estevez, Y., Lancha-Tangoa, A., Alban-Castillo, J., Deharo, E., Rojas, R., Stien, D. and Sauvain, M. (2009) Ta'ta', Huayani: Perception of Leishmaniasis and Evaluation of Medicinal Plants Used by the Chayahuita in Peru. Part II. Journal of Ethnopharmacology, 126, 149-158. http://dx.doi.org/10.1016/j.jep.2009.07.015

[35] Deharo, E., Bourdy, G., Quenevo, C., Muñoz, V., Ruiz, G. and Sauvain, M. (2001) A Search for Natural Bioactive Compounds in Bolivia through a Multidisciplinary Approach. Part V. Evaluation of the Antimalarial Activity of Plants Used by the Tacana Indians. Journal of Ethnopharmacology, 77, 91-98. http://dx.doi.org/10.1016/S0378-8741(01)00270-7

[36] Graham, J.G., Pendland, S.L., Prause, J.L., Danzinger, L.H., Vigo, J.S., Cabieses, F. and Farnsworth, N.R. (2003) Antimycobacterial Evaluation of Peruvian Plants. Phytomedicine, 10, 528-535.

http://dx.doi.org/10.1078/094471103322331502 
[37] Wen, L., Haddad, M., Fernandez, I., Espinoza, G., Ruiz, C., Neyra, E., Bustamante, B. and Rojas, R. (2011) Antifungal Activity of Four Plants Used in Peruvian Traditional Medicine: Isolation of the Active Principle of Psidium acutangulum. Revista de la Sociedad Quimica del Peru, 77, 199-204.

[38] Jovel, E.M., Cabanillas, J. and Towers, G.H.N. (1996) An Ethnobotanical Study of the Traditional Medicine of the Mestizo People of Suni Mirano, Loreto, Perú. Journal of Ethnopharmacology, 53, 149-156. http://dx.doi.org/10.1016/0378-8741(96)01437-7

[39] Polesna, L., Polesny, Z., Clavo, M.Z., Hansson, A. and Kokoska, L. (2011) Ethnopharmacological Inventory of Plants Used in Coronel Portillo Province of Ucayali Department, Peru. Pharmaceutical Biology, 49, 125-136. http://dx.doi.org/10.3109/13880209.2010.504927

[40] Castillo, D., Arevalo, J., Herrera, F., Ruiz, C., Rojas, R., Rengifo, E., Vaisberg, A., Lockb, O., Lemesre, J.L., Gornitzka, H. and Sauvain, M. (2007) Spirolactone Iridoids Might Be Responsible for the Antileishmanial Activity of a Peruvian Traditional Remedy Made with Himatanthus sucuuba (Apocynaceae). Journal of Ethnopharmacology, 112, 410414. http://dx.doi.org/10.1016/j.jep.2007.03.025

[41] Cardoso, C.L., Silva, D.H.S., Tomazela, D.M., Verli, H., Young, M.C.M., Furlan, M., Eberlin, M.N. and da Silva Bolzani, V. (2003) Turbinatine, a Potential Key Intermediate in the Biosynthesis of Corynanthean-Type Indole Alkaloids. Journal of Natural Products, 66, 1017-1021. http://dx.doi.org/10.1021/np020547m

[42] Cardoso, C.L., Castro-Gamboa, I., Silva, D.H.S., Furlan, M., Epifanio, R.D.A., da Cunha Pinto, A., de Rezende, C.M., Lima, J.A. and da Silva Bolzani, V. (2004) Indole Glucoalkaloids from Chimarrhis turbinata and Their Evaluation as Antioxidant Agents and Acetylcholinesterase Inhibitors. Journal of Natural Products, 67, 1882-1885. http://dx.doi.org/10.1021/np049863m

[43] Cardoso, C.L., Silva, D.H.S., Castro-Gamboa, I. and da Silva Bolzani, V. (2005) New Biflavonoid and Other Flavonoids from the Leaves of Chimarrhis turbinate and Their Antioxidant Activities. Journal of the Brazilian Chemical Society, 16, 1353-1359. http://dx.doi.org/10.1590/S0103-50532005000800008

[44] Cardoso, C.L., da Silva Bolzani, V., Silva, D.H.S., Ishii, H., Berova, N. and Nakanishi, K. (2006) The Absolute Configuration of 1-(3',4'-Dihydroxycinnamoyl)Cyclopentane-2,3-diol from the Amazonian Tree Chimarrhis turbinate. Journal of Natural Products, 69, 1046-1050. http://dx.doi.org/10.1021/np050522y

[45] Cardoso, C.L., Castro-Gamboa, I., Bergamini, G.M., Cavalheiro, A.J., Silva, D.H.S., Lopes, M.N., Araujo, A.R., Furlan, M., Verli, H. and da Silva Bolzani, V. (2011) An Unprecedented Neolignan Skeleton from Chimarrhis turbinata. Journal of Natural Products, 74, 487-491. http://dx.doi.org/10.1021/np1007476

[46] Bertani, S., Bourdy, G., Landau, I., Robinson, J.C., Esterre, P. and Deharo, E. (2005) Evaluation of French Guiana Traditional Antimalarial Remedies. Journal of Ethnopharmacology, 98, 45-54. http://dx.doi.org/10.1016/j.jep.2004.12.020

[47] Gunatilaka, A.A.L., Samaranayake, G. and Kingston, D.G.I. (1992) Bioactive Ergost-5-ene-3ß,7a-diol Derivatives from Pseudobersama mossambicensis. Journal Natural Products, 55, 1648-1654. http://dx.doi.org/10.1021/np50089a014

[48] Sanz-Biset, J. and Cañigueral, S. (2011) Plant Use in the Medicinal Practices Known as "Strict Diets" in Chazuta Valley (Peruvian Amazon). Journal of Ethnopharmacology, 137, 271-288. http://dx.doi.org/10.1016/j.jep.2011.05.021

[49] Moraes, F., Hahn, M.G. and Braga, M.R. (2001) Comparative Analysis of Leaf Cell-Wall Polysaccharides of Dialypetalanthus fuscescens and Bathysa meridionalis: Evidence of Biochemical Similarities between Dialypetalanthaceae and Rubiaceae-Cinchonoideae. Revista Brasileira de Botânica, 24, 289-294. http://dx.doi.org/10.1590/S0100-84042001000300007

[50] Aldana, J., Téllez, N. and Gamboa, F. (2013) Antimicrobial Activity of Fractions and Subfractions of Elaegia utilis against Microoganisms of Importance in Dental Caries. Acta Odontológica Latinoamericana, 26, 104-111.

[51] Quiros, D.I., Emmen, D.A., Dominguez, E., Heller, M.V., Coley, P.D. and Kursar, T.A. (2006) A Rapid, Efficient Method for the Bioassay of Extracts, Fractions and Compounds for Activity against Tropical Aphids. International Journal of Pest Management, 52, 333-342. http://dx.doi.org/10.1080/09670870600847525

[52] Ma, Z.W. and He, G.F. (1989) Chemical Constituents of Emmenopterys henryi Oliv. Native to China. Acta Botanica Sinica, 31, 620-625.

[53] Wu, X.D., He, J., Li, X.Y., Dong, L.B., Gong, X., Gao, X., Song, L.D., Li Y., Peng, L.Y. and Zhao, Q.S. (2013) Triterpenoids and Steroids with Cytotoxic Activity from Emmenopterys henryi. Planta Medica, 79, 1356-1361. http://dx.doi.org/10.1055/s-0033-1350645

[54] Liu, T.X., Xu, H.H. and Luo, W.C. (2006) Opportunities and Potentials of Botanical Extracts and Products for Management of Insect Pests in Cruciferous Vegetables. Naturally Occurring Bioactive Compounds, 8, 171-197. http://dx.doi.org/10.1016/S1572-557X(06)03008-X

[55] Odonne, G., Valadeau, C., Alban-Castillo, J., Stien, D., Sauvain, M. and Bourdy, G. (2013) Medical Ethnobotany of 
the Chayahuita of the Paranapura Basin (Peruvian Amazon). Journal of Ethnopharmacology, 146, 127-153. http://dx.doi.org/10.1016/j.jep.2012.12.014

[56] Li, X.C., Jacob, M.R., ElSohly, H.N., Nagle, D.G., Smillie, T.J., Walker, L.A. and Clark, A.M. (2003) Acetylenic Acids Inhibiting Azole-Resistant Candida albicans from Pentagonia gigantifolia. Journal of Natural Products, 66, 11321135. http://dx.doi.org/10.1021/np030196r

[57] Delprete, P.G. (1996) Systematics, Typification, Distribution, and Reproductive Biology of Pinckneya bracteata (Rubiaceae). Plant Systematics and Evolution, 201, 243-261. http://dx.doi.org/10.1007/BF00989065

[58] Ito, A., Lee, Y.H., Chai, H.B., Gupta, M.P., Farnsworth, N.R., Cordell, G.A., Pezzuto, J.M. and Kinghorn, A.D. (1999) 1',2',3',4'-Tetradehydrotubulosine, a Cytotoxic Alkaloid from Pogonopus speciosus. Journal of Natural Products, 62, 1346-1348. http://dx.doi.org/10.1021/np990255u

[59] Sauvain, M., Moretti, C., Bravo, J.A., Callapa, J., Muñoz, V., Ruiz, E., Richard, B. and Le Men-Olivier, L. (1996) Antimalarial Activity of Alkaloids from Pogonopus tubulosus. Phytotherapy Research, 10, 198-201. http://dx.doi.org/10.1002/(SICI)1099-1573(199605)10:3<198::AID-PTR798>3.0.CO;2-Z

[60] Perdomo, R.T. (2011) Evaluation of the Antiproliferative Activity and Inhibition of Topoisomerases by Extracts, Pure and Semi-Synthetic Substances Obtained from Natural Products. Doutorate Degree Thesis, Federal University of Mato Grosso do Sul, Campo Grande.

[61] Desjardins, R.E., Canfield, C.J., Haynes, J.D. and Chulay, J.D. (1979) Quantitative Assessment of Antimalarial Activity in Vitro by a Semi-Automated Microdilution Technique. Antimicrobial Agents and Chemotherapy, 16, 710-718. http://dx.doi.org/10.1128/AAC.16.6.710

[62] Frederich, M., Tits, M. and Angenot, L. (2008) Potential Antimalarial Activity of Indole Alkaloids. Royal Society of Tropical Medicine and Hygiene, 102, 11-19. http://dx.doi.org/10.1016/j.trstmh.2007.10.002

[63] Vieira, R.C., Delprete, P.G., Leitão, G.G. and Leitão, S.G. (2001) Anatomical and Chemical Analyses of Leaf Secretory Cavities of Rustia formosa (Rubiaceae). American Journal of Botany, 88, 2151-2156. http://dx.doi.org/10.2307/3558376

[64] Li, X.C., Jacob, M.R., Khan, S.I., Ashfaq, M.K., Babu, K.S., Agarwal, A.K., ElSohly, H.N., Manly, S.P. and Clark, A.M. (2008) Potent in Vitro Antifungal Activities of Naturally Occurring Acetylenic Acids. Antimicrobial Agents and Chemotherapy, 52, 2442-2448. http://dx.doi.org/10.1128/AAC.01297-07

[65] Loustalot, A.J. and Pagan, C. (1949) Local “Fever” Plants Tested for Presence of Alkaloids. El Crisol, 3, 3-5.

[66] Mohammed, M.J. and Seaforth, C.E. (1981) Extractives of Warszewiczia coccinea Klotzch. Revista Latinoamericana de Quimica, 12, 72-73.

[67] Estevez, Y., Castillo, D., Pisango, M.T., Arevalo, J., Rojas, R., Alban, J., Deharo, E. and Bourdy, G. (2007) Sauvain, M. Evaluation of the leishmanicidal Activity of Plants Used by Peruvian Chayahuita Ethnic Group. Journal of Ethnopharmacology, 114, 254-259. http://dx.doi.org/10.1016/j.jep.2007.08.007

[68] Valadeau, C., Pabon, A., Deharo, E., Albán-Castillo, J., Estevez, Y., Lores, F.A., Rojas, R., Gamboa, D., Sauvain, M., Castillo, D. and Bourdy, G. (2009) Medicinal Plants from the Yanesha (Peru): Evaluation of the Leishmanicidal and Antimalarial Activity of Selected Extracts. Journal of Ethnopharmacology, 123, 413-422. http://dx.doi.org/10.1016/j.jep.2009.03.041

[69] Cunha, A.P. (2005) Farmacognosia e fitoquímica. Fundação Calouste Gulbenkian, Lisboa, 403-412. 